\title{
Lack of significant association of an insertion/deletion polymorphism in the angiotensin converting enzyme (ACE) gene with tropical calcific pancreatitis
}

\author{
Seema Bhaskar1 ${ }^{1}$ DN Reddy², Swapna Mahurkar ${ }^{1}$, GV Rao ${ }^{2}$, Lalji Singh ${ }^{1}$ and \\ Giriraj R Chandak*1
}

Address: ${ }^{1}$ Genome Research Group, Centre for Cellular and Molecular Biology, Uppal Road, Hyderabad 500007 , India and ${ }^{2}$ Asian Institute of Gastroenterology, Punjagutta, Hyderabad 500 082, India

Email: Seema Bhaskar - seema@ccmb.res.in; DN Reddy - aigindia@yahoo.co.in; Swapna Mahurkar - mahurkar@ccmb.res.in; GV Rao - aigindia@yahoo.co.in; Lalji Singh - lalji@ccmb.res.in; Giriraj R Chandak* - chandakgrc@ccmb.res.in

* Corresponding author

Published: 12 December 2006

BMC Gastroenterology 2006, 6:42 doi:I0.1 I86/147|-230X-6-42

This article is available from: http://www.biomedcentral.com/I47I-230X/6/42

(C) 2006 Bhaskar et al; licensee BioMed Central Ltd.

This is an Open Access article distributed under the terms of the Creative Commons Attribution License (http://creativecommons.org/licenses/by/2.0), which permits unrestricted use, distribution, and reproduction in any medium, provided the original work is properly cited.

\begin{abstract}
Background: The genetic basis of tropical calcific pancreatitis (TCP) is different and is explained by mutations in the pancreatic secretory trypsin inhibitor (SPINKI) gene. However, mutated SPINKI does not account for the disease in all the patients, neither does it explain the phenotypic heterogeneity between TCP and fibro-calculous pancreatic diabetes (FCPD). Recent studies suggest a crucial role for pancreatic renin-angiotensin system during chronic hypoxia in acute pancreatitis and for angiotensin converting enzyme (ACE) inhibitors in reducing pancreatic fibrosis in experimental models. We investigated the association of $A C E$ gene insertion/deletion (I/D) polymorphism in TCP patients using a case-control approach. Since SPINKI mutations are proposed a modifier role, we also investigated its interaction with the ACE gene variant.
\end{abstract}

Methods: We analyzed the I/D polymorphism in the ACE gene (g.II4I7_II704del287) in I7I subjects comprising $91 \mathrm{TCP}$ and 80 FCPD patients and compared the allelic and genotypic frequency in them with 99 healthy ethnically matched control subjects.

Results: We found $46 \%$ and $21 \%$ of TCP patients, $56 \%$ and $19.6 \%$ of FCPD patients and $54.5 \%$ and $19.2 \%$ of the healthy controls carrying the $I / D$ and $D / D$ genotypes respectively $(P>0.05)$. No significant difference in the clinical picture was observed between patients with and without the del allele at the $A C E$ in/del polymorphism in both categories. No association was observed with the presence or absence of N34S SPINKI mutation in these patients.

Conclusion: We conclude that the ACE insertion/deletion variant does not show any significant association with the pathogenesis, fibrosis and progression of tropical calcific pancreatitis and the fibro-calculous pancreatic diabetes.

\section{Background}

Chronic Pancreatitis (CP) is a major health care problem worldwide and is associated with varied etiologies. CP is identified clinically by loss of endocrine and/or exocrine 
functions and pathologically by the presence of chronic inflammation and fibrosis of the pancreas $[1,2]$. Tropical calcific pancreatitis (TCP) is a form of chronic pancreatitis of unknown etiology, more prevalent in the tropical regions of developing countries such as India whereas fibrocalculous pancreatic diabetes (FCPD) is a form of diabetes secondary to TCP [3]. Both TCP and FCPD are associated with extensive fibrosis involving both intra and inter-lobular regions and not limited to one zone of the pancreas, although the extent of fibrosis varies and is usually more in FCPD [4]. We and several others previously demonstrated an absence of mutations in the cationic trypsinogen gene (PRSS1) and a higher frequency of N34S mutation in the pancreatic secretory trypsin inhibitor (encoded by SPINK1 gene) in both FCPD and TCP patients without diabetes mellitus suggesting a common genetic basis for them $[5,6]$. However, other genetic and/ or environmental factors may explain the phenotypic variability in FCPD and TCP patients without diabetes [5].

The renin-angiotensin system (RAS) plays a central role in health and disease by maintaining the electrolyte and fluid balance and in turn, the blood pressure [7]. Apart from circulating RAS, several studies suggest the existence of local RAS components in tissues such as brain, heart, kidney, pancreas, adrenals and gonads [8,9]. Tissue specific RAS can act locally as paracrine and/or autocrine factors in meeting specific needs of individual tissues [10] and any functional alterations may be associated with pathophysiology of respective tissue/organ functions [1113]. An intrinsic renin-angiotensin system (RAS) is present in the pancreas. Angiotensin converting enzyme (ACE), a zinc metallopeptidase is a key enzyme of this system [14]. ACE and RAS activity is known to be enhanced during acute pancreatitis and chronic hypoxia in experimental animals $[15,16]$. ACE cleaves angiotensin (AT)-I to AT-II, which induces proliferation of hepatic stellate cells (HSCs) and synthesis of extracellular matrix proteins by increasing the expression of transforming growth factorbeta $[17,18]$. Isolated pancreatic stellate cells are similar to HSCs [19] and known to be involved in pathogenesis of pancreatic fibrosis in both experimental animals and humans [20]. Increased accumulation of extra-cellular matrix is a histological characteristic of chronic pancreatitis that results in pancreatic fibrosis [21]. In addition, ACE inhibitors have recently been demonstrated to attenuate pancreatic inflammation and fibrosis in spontaneously occurring chronic pancreatitis in male Wistar Bonn/ Kobori rats [22].

A polymorphism within intron 16 (g.11417_11704del287) of the ACE gene is strongly related to the circulating enzyme levels in a dose dependent manner [23]. The DD genotype that is associated with higher levels of circulating ACE than the II and ID geno- types, is known to be significantly more frequent in patients with myocardial infarction or patients with diabetic proteinuria than in controls $[24,25]$. Thus, ACE gene polymorphisms may play a role in the pathogenesis of chronic pancreatitis and several other pancreatic diseases including acute pancreatitis, pancreatic cancer, diabetes mellitus and cystic fibrosis. Although a recent study failed to find any association of ACE I/D polymorphism in familial and sporadic chronic pancreatitis, we hypothesized a role for this polymorphism in view of the extensive fibrosis observed in the TCP patients [26]. In this study, we investigated the ACE gene I/D polymorphism in TCP patients (without diabetes mellitus), FCPD patients and healthy controls to understand its association with the disease. Since, SPINK1 mutations are proposed to play a modifier role, we also investigated whether any association exists with the I/D polymorphism in the ACE gene.

\section{Methods \\ Patients and controls}

A total of 171 unrelated patients $(120 \mathrm{M}+51 \mathrm{~F})$ comprising of 91 TCP and 80 FCPD patients were recruited in the study based on the WHO criteria [27]. 99 unrelated ethnically matched individuals with complaints of dyspepsia were recruited as controls after a similar set of investigations excluded the disease in them. These individuals filled the same questionnaire and underwent similar investigations as the patients especially the imaging procedures which included computed tomography, endoscopic ultrasonography, magnetic resonance cholangiopancreatography and endoscopic retrograde cholangiopancreatography, wherever indicated [5]. All the patients and healthy controls were explained the purpose of the study and the complications of investigative procedures and peripheral blood samples were collected after they signed the written informed consent. The study was approved by the institutional ethics committee of respective institutes following the Indian Council of Medical Research guidelines for handling human samples.

\section{Genetic analysis}

Genomic DNA was isolated from peripheral blood leucocytes following standard protocols [28]. The genotype at I/ D variant was determined by PCR amplification of genomic DNA fragment in intron 16 of the ACE gene using forward and reverse primers, 5'-CCACTCCCATCCTTTCTCC-3' and 5'-GGCCATCACATTCGTCAGA-3' respectively. The position of the amplified region in the gene covering the polymorphism was 11417-11595 (as per NT_010783). PCR was performed using cycling conditions of initial denaturation at $94^{\circ} \mathrm{C}$ for $3 \mathrm{~min}$, followed by 35 cycles of denaturation at $94^{\circ} \mathrm{C}$ for $1 \mathrm{~min}$, annealing at $59^{\circ} \mathrm{C}$ for $1 \mathrm{~min}$ and extension at $72^{\circ} \mathrm{C}$ for $1 \mathrm{~min} 30 \mathrm{sec}$, with a final 5 min extension at $72^{\circ} \mathrm{C}$. PCR products of approximate $179 \mathrm{bp}$ (without insertion) and approximate 
466 bp (with 287 bp insertion) were detected by electrophoresis on a $2 \%$ agarose-gel containing ethidium bromide as shown in figure 1 . Genotyping was repeated if any ambiguity was noted in the observations. The primer sequences and PCR conditions for analysis of the promoter region and four exons of the SPINK1 gene were selected from Witt et al. [29]. All the exons were sequenced individually on both the strands using internal sequencing primers and Big dye terminator cycle sequencing ready kit and an ABI 3730 Genetic Analyzer (Applied Biosystems) [5]. 10\% of randomly selected samples were sequenced to confirm the genotypes.

\section{Statistical analysis}

Allele frequency was calculated by the allele counting method, which was then utilized to determine the genotype frequency. The patients were divided into TCP and FCPD based on the presence or absence of diabetes mellitus and further based on the status of N34S SPINK1 mutation and ACE in/del polymorphism. Statistical comparisons were carried out by using Pearson's Chisquared test, unpaired t-test and odds ratios (OR) along with the 95\% confidence interval (CI). Two-tailed P values less than 0.05 were considered statistically significant. Post-hoc power analysis showed the study being adequately powered $(84.6 \%)$ to accept the null hypothesis that the I/D polymorphism in ACE gene is not associated with TCP $(\alpha=0.05, \beta=-1.426)$ [30].

\section{Results and discussion}

Tropical calcific pancreatitis is a form of chronic pancreatitis associated with fibrosis and pancreatic calcification. FCPD, a form of diabetes secondary to TCP, is thought to occur due to pancreatic destruction as a result of fibrosis and calcification [3]. We investigated the association of I/ $\mathrm{D}$ polymorphism in the ACE gene with TCP and the phenotype of diabetes in FCPD.

The median age at onset and age at presentation for FCPD patients was $32.6 \mathrm{yrs}$ (95\% CI 29.6-35.6) and 40.9 yrs (95\% CI 37.8-44.0), which is significantly higher than that of TCP patients without diabetes mellitus [(25.8 yrs, 95\% CI 23.5-28.1, $\mathrm{P}=0.004)$ and (33.9 yrs, 95\% CI 31.6-36.2, $\mathrm{P}=0.001$ ) respectively] (table 1 ). However, the duration of disease was similar in either category. As suggested earlier, FCPD represents a late stage manifestation of TCP $[5,31]$.

We did not observe any significant difference either in the allele frequency or in the genotype distribution of the I/D polymorphism at ACE locus between patients and controls (D allele frequency; 0.46 and 0.47 respectively) and between TCP and FCPD patients ( $\mathrm{D}$ allele frequency; 0.44 and 0.48 respectively) (table 2 ). No deviation from Hardy-Weinberg equilibrium was observed $(P>0.05)$.
Since frequency of mutated SPINK1 is reported to be similar in TCP and FCPD patients $[5,6]$, we investigated whether the I/D variant in ACE gene can explain the phenotypic variability between them. We did not observe any association of the ACE I/D polymorphism with various phenotypic features including the age of onset and age of presentation, pancreatic calcification or surgeries (table 3 ). Table 4 summarizes the allele frequency and genotype distribution of I/D polymorphism in patients and the controls based on the presence or absence of N34S SPINK1 mutation (irrespective of their zygosity, heterozygous or homozygous genotypes). Of 91 TCP patients, 60 carried the wild type allele while 31 (34\%) had at least one copy of the mutant allele at N34S SPINK1 variant. Genotypic distribution of the I/D variant was similar in the patient groups with and without N34S mutation in SPINK1 gene as well as in TCP and FCPD patient group and the normal individuals. Among TCP patients carrying mutated SPINK1, 15 (48\%) patients were heterozygous for I/D ACE variant and 5 (16\%) carried the DD genotype whereas of 41 patients without N34S SPINK1 mutation, 27 (45\%) had I/D genotype and 14 (23\%) carried DD genotype at the ACE locus. Similar observations were made for the group of 80 FCPD patients with and without N34S mutation in the SPINK1 gene. This suggests that there is no interaction between the I/D variant in the ACE gene and the N34S mutation in the SPINK1 gene in either TCP or FCPD patients. It may be interesting to investigate whether other variants in the ACE gene or any specific haplotype may explain the role of ACE in TCP and FCPD.

Angiotensin converting enzyme catalyzes the conversion of angiotensin I into the vasoactive and aldosterone-stimulating peptide angiotensin II [14], which carries out its biological functions by binding to two receptors, AT1R and AT2R [32]. Several studies have suggested the presence of a pancreatic RAS, having physiological effects via a paracrine/autocrine pattern in the exocrine and endocrine pancreas, probably in the regulation of pancreatic microcirculation, ductal anion secretion and islet hormonal secretion [9]. Both circulating and intrinsic pancreatic ACE activity is markedly elevated during acute and chronic inflammation of the pancreas $[15,16]$. Recent studies have shown that ACE enzyme directs pancreatic fibrogenesis in experimental animals [33] and inhibition of the RAS system with an ACE inhibitor attenuates pancreatic inflammation and fibrosis in an animal model of chronic pancreatitis [22]. Thus, angiotensinogen-II converted endogenously from angiotensinogen-I by circulating ACE may be directly involved in the induction of pancreatic inflammation and development of pancreatic fibrosis in the spontaneously occurring chronic pancreatitis in male Wistar Bonn/Kobori (WBN/Kob) rats [22]. However, our study failed to observe any association 


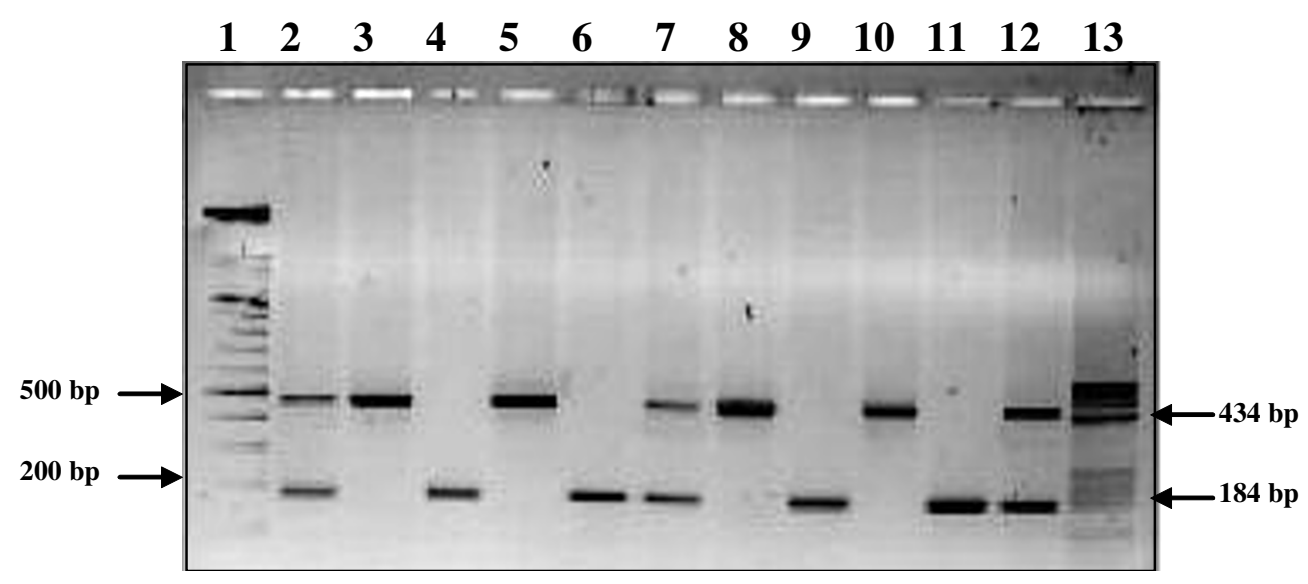

\section{Figure I}

Agarose gel electrophoresis showing genotypes at in/del polymorphism in the ACE gene (g. I I4I7_II 704del287). Lanes I \& I3 represent DNA marker XIV (New England Biolabs, USA) and marker V (Boerhinger Manheim, Germany), Lane 2:Control for genotype ID, Lane 3:Control for genotype II, Lane 4:Control for genotype DD. Lanes 5, 8, I0 show II genotype, lanes 7 and I 2 are ID genotypes and lanes 6, 9, II carry the DD genotype. bp, base-pair

between I/D variant and TCP or FCPD patients irrespective of N34S SPINK1 mutation status.

Our results are in agreement with the recent study on familial and sporadic chronic pancreatitis patients, which showed that the insertion/deletion polymorphism in the $A C E$ gene does not make a significant contribution to the pathogenesis and progression of the disease [26]. Although, recent evidence suggests that TCP is a specific genetic entity [5], there may be certain overlapping features with idiopathic chronic pancreatitis (ICP). In fact, the nomenclature of idiopathic chronic pancreatitis is itself a matter of debate since genetic etiology appears to play an important role in both ICP and TCP in India [34]. Thus, ACE I/D polymorphism may not contribute to the pathogenesis of TCP despite the fact that the RAS system specifically affects the pancreas, an indication that local effects are more important than the systemic ones in pancreatic diseases. In the absence of intra-pancreatic ACE levels in these patients, there may exist a possibility that in contrast to other tissues such as heart and renal tissue, DD genotype does not influence the ACE gene expression and consequently its levels in the pancreas.

\section{Conclusion}

We conclude that the insertion/deletion polymorphism at the ACE locus does not play any role in the causation and progression of TCP. Further studies focusing on other environmental and/or genetic factors such as mutations in the CFTR gene may explain the phenotypic variability between TCP and FCPD patients.

\section{Abbreviations \\ AT Angiotensin \\ CP Chronic pancreatitis \\ CI Confidence interval}

ACE Angiotensin converting enzyme

Table I: Characteristics of the study population

\begin{tabular}{|c|c|c|c|}
\hline & TCP & FCPD & Total \\
\hline $\mathbf{n}$ & 91 & 80 & $|7|$ \\
\hline Sex (Male/Female) & $61 \mathrm{M} / 30 \mathrm{~F}$ & $59 \mathrm{M} / 2 \mathrm{IF}$ & $120 \mathrm{M} / 5 \mathrm{I} \mathrm{F}$ \\
\hline Age at onset (yrs) & $25.8(23.5-28.1)$ & $32.6(29.6-35.6)$ & $28.0(26.0-30.0)$ \\
\hline Age at presentation (yrs) & $33.9(31.6-36.2)$ & $40.9(37.8-44.0)$ & $36.4(34.4-38.4)$ \\
\hline Duration of symptoms (yrs) & $8.8(7.5-10.1)$ & $10.0(8.4-11.6)$ & $9.3(8.3-10.3)$ \\
\hline Age at onset of diabetes (yrs) & NA & $33.8(31.0-36.6)$ & NA \\
\hline Duration of diabetes (yrs) & NA & $7.2(5.8-8.6)$ & NA \\
\hline
\end{tabular}

n, number of patients; yrs, years; TCP, tropical calcific pancreatitis; FCPD, fibro-calculous pancreatic diabetes $\mathrm{NA}$, not applicable; Figures are quoted as median, range $95 \% \mathrm{Cl}$ 
Table 2: Allele frequency and genotype distribution of I/D polymorphism at ACE locus in TCP patients \& control subjects

\begin{tabular}{|c|c|c|c|c|c|c|c|}
\hline & \multicolumn{3}{|c|}{ Patients } & \multirow[t]{2}{*}{ Controls } & \multicolumn{3}{|c|}{ P Value } \\
\hline & TCP & FCPD & Total & & TCP vs. FCPD & TCP vs. controls & FCPD vs. controls \\
\hline $\mathbf{n}$ & 91 & 80 & $|7|$ & 99 & - & - & - \\
\hline \multicolumn{8}{|c|}{ Allele frequency } \\
\hline $\mathbf{I}$ & 0.56 & 0.52 & 0.54 & 0.53 & 0.57 & 0.67 & 0.89 \\
\hline D & 0.44 & 0.48 & 0.46 & 0.47 & & & \\
\hline \multicolumn{8}{|c|}{$\begin{array}{l}\text { Genotype frequency based on the presence or } \\
\text { absence of the mutant allele }\end{array}$} \\
\hline II & $0.33(30)$ & $0.24(19)$ & $0.29(49)$ & $0.26(26)$ & 0.16 & 0.28 & 0.74 \\
\hline ID + DD & $0.67(61)$ & $0.76(61)$ & $0.71(122)$ & $0.74(73)$ & & & \\
\hline
\end{tabular}

n, number of individuals; TCP, tropical calcific pancreatitis; FCPD, fibro-calculous pancreatic diabetes; ACE, angiotensin converting enzyme; I/D, insertion/deletion polymorphism at ACE locus figures in parentheses indicate number of individuals; $\mathrm{P}$ values are represented on comparison of TCP with FCPD, TCP with controls and FCPD with controls.

Table 3: Clinical features of TCP and FCPD patients grouped according to their genotype at in/del polymorphism at ACE gene

\begin{tabular}{|c|c|c|c|c|c|c|c|c|c|}
\hline & \multicolumn{3}{|c|}{ TCP } & \multicolumn{3}{|c|}{ FCPD } & \multicolumn{3}{|c|}{ Total } \\
\hline & II & ID/DD & $P$ value & II & ID/DD & $P$ value & II & ID/DD & P value \\
\hline $\mathbf{n}$ & 30 & 61 & - & 19 & 61 & - & 49 & 122 & - \\
\hline Sex (Male/Female) & $22 / 8$ & $39 / 22$ & - & $17 / 2$ & $42 / 19$ & - & $39 / 10$ & $81 / 41$ & - \\
\hline Age at onset (yrs) & $25.7 \pm 11.1$ & $24.8 \pm 11.8$ & 0.72 & $34.4 \pm 15.1$ & $31.2 \pm 12.9$ & 0.37 & $29.0 \pm 13.3$ & $28.0 \pm 12.7$ & 0.64 \\
\hline Age at presentation (yrs) & $36.2 \pm 11.8$ & $32.7 \pm 10.9$ & 0.16 & $40.3 \pm 17.0$ & $38.9 \pm 13.9$ & 0.72 & $37.8 \pm 14.0$ & $35.8 \pm 12.9$ & 0.37 \\
\hline Age at onset of diabetes (yrs) & NA & NA & NA & $34.2 \pm 13.9$ & $33.7 \pm 11.44$ & 0.88 & $34.2 \pm 13.9$ & $33.7 \pm 11.4$ & 0.81 \\
\hline Pancreatic surgery & II (36.67\%) & $24(40 \%)$ & 0.76 & $2(10.53 \%)$ & $4(6.56 \%)$ & 0.57 & $13(26.53 \%)$ & $28(23.14 \%)$ & 0.64 \\
\hline Calcification & $30(100 \%)$ & 61 (100\%) & 1 & $19(100)$ & $61(100)$ & 1 & $49(100)$ & $122(100)$ & I \\
\hline Pseudocyst & $2(6.67 \%)$ & $4(6.6 \%)$ & 1 & $0(0 \%)$ & $\mathrm{I}(\mathrm{I} .64)$ & 1 & $2(4.08 \%)$ & $5(4.13 \%)$ & 1 \\
\hline
\end{tabular}

$\mathrm{n}$, number of individuals; TCP, tropical calcific pancreatitis; FCPD, fibro-calculous pancreatic diabetes; $A C E$, angiotensin converting enzyme

$I / D$, insertion/deletion polymorphism at ACE locus; NA, not applicable; figures in parentheses indicate percentage; figures are quoted as mean \pm SD

$P$ values are represented on comparison of II vs ID+DD genotypes in TCP, FCPD and total patients

Table 4: Allele frequency and genotype distribution of I/D polymorphism at ACE locus in TCP patients and controls based on their N34S SPINKI status

\begin{tabular}{|c|c|c|c|c|c|c|c|c|c|c|c|}
\hline \multirow[b]{3}{*}{ N34S SPINKI mutation status } & \multicolumn{8}{|c|}{ Patients } & \multicolumn{3}{|c|}{ Controls } \\
\hline & \multicolumn{2}{|c|}{ TCP } & \multirow[t]{2}{*}{ P Value } & \multicolumn{2}{|c|}{ FCPD } & \multirow[t]{2}{*}{ P Value } & \multicolumn{2}{|c|}{ Total } & \multirow[t]{2}{*}{ P Value } & \multirow[b]{2}{*}{ Mutant $\$$} & \multirow[b]{2}{*}{ Wild } \\
\hline & Mutant* & Wild & & Mutant" & Wild & & Mutant & Wild & & & \\
\hline $\mathbf{N}$ & 31 & 60 & & 21 & 59 & & 52 & 119 & & 3 & 96 \\
\hline \multicolumn{12}{|l|}{ Allele frequency } \\
\hline $\mathbf{I}$ & 0.60 & 0.54 & 0.39 & 0.55 & 0.51 & 0.57 & 0.58 & 0.53 & 0.48 & 0.67 & 0.53 \\
\hline D & 0.40 & 0.46 & & 0.45 & 0.49 & & 0.42 & 0.47 & & 0.33 & 0.47 \\
\hline \multicolumn{12}{|c|}{$\begin{array}{l}\text { Genotype frequency based on the } \\
\text { presence or absence of the mutant } \\
\text { allele }\end{array}$} \\
\hline II & $0.36(11)$ & $0.32(19)$ & 0.55 & $0.29(06)$ & $0.22(13)$ & 0.26 & $0.33(17)$ & $0.27(32)$ & 0.35 & $0.33(0 \mathrm{I})$ & $0.26(25)$ \\
\hline ID + DD & $0.64(20)$ & $0.68(4 I)$ & & $0.71(15)$ & $0.78(46)$ & & $0.67(35)$ & $0.73(87)$ & & $0.67(02)$ & $0.74(7 \mathrm{I})$ \\
\hline
\end{tabular}

n, number of individuals; TCP, tropical calcific pancreatitis; FCPD, fibro-calculous pancreatic diabetes; ACE, angiotensin converting enzyme; I/D, insertion/deletion polymorphism at $\mathrm{ACE}$ locus figures in parentheses indicate number of individuals; $\mathrm{P}$ value is represented on comparison of $\mathrm{N} 34 \mathrm{~S}$ SPINKI positive vs. N34S negative TCP, FCPD and total patients.

*, includes 9 N34S SPINKI homozygotes and 22 heterozygotes; \# includes 4 N34S SPINKI homozygotes and I7 heterozygotes, \$, includes 3 N34S SPINKI heterozygotes 
FCPD Fibrocalculous pancreatic diabetes

HSCs Hepatic stellate cells

ICP Idiopathic chronic pancreatitis

OR Odds ratio

PRSS1 Protease, serine, 1 (trypsin 1)

RAS Renin-angiotensin system

TCP Tropical calcific pancreatitis

SPINK1 Serine protease inhibitor, Kazal type I

WHO World Health Organization

\section{Competing interests}

The author(s) declare that they have no competing interests.

\section{Authors' contributions}

SB carried out the molecular genetic studies including sequencing analysis, DNR and GVR designed studies of the phenotypes, identified and diagnosed the patients, SM performed the statistical analysis, GRC conceptualized, designed the study and drafted the manuscript. All authors read and approved the final manuscript.

\section{Acknowledgements}

The authors are grateful to all the patients and the normal individuals for agreeing to participate in the study and particularly for giving consent for genetic studies. Thanks are also due to Dr Ramakrishna, Asian Institute of Gastroenterology for his help in recruitment of patients and collection of blood samples. The financial support of Council of Scientific and Industrial Research, Ministry of Science and Technology, Government of India is gratefully acknowledged.

\section{References}

I. Ammann RW: Natural history of chronic pancreatitis. Dig Surg 1994, I I:267-274.

2. Steer MI, Waxman I, Freedman S: Chronic pancreatitis. N Engl J Med 1995, 332: | 482-90.

3. Mohan V, Chari ST, Hitman GA, Suresh S, Madanagopalan N, Ramachandran A, Viswanathan M: Familial aggregation in tropical fibrocalculous pancreatic diabetes. Pancreas 1989, 4:690-693.

4. Nagalotimath S]: Pancreatic pathology in pancreatic calcification with diabetes. In Secondary diabetes: The spectrum of the diabetic syndromes Edited by: Podolsky S, Viswanathan M. New York: Raven Press; 1980: I 17-145.

5. Chandak GR, Idris MM, Reddy DN, Bhaskar S, Sriram PVJ, Singh L: Mutations in the pancreatic secretory trypsin inhibitor gene (PSTIISPINKI) rather than the cationic trypsinogen gene (PRSSI) are significantly associated with tropical calcific pancreatitis. I Med Genet 2002, 39:347-35I.

6. Hassan Z, Mohan V, Ali L, Allotey R, Barakat K, Faruque MO, Deepa R, McDermott MF, Jackson AE, Cassell P, Curtis D, Gelding SV, Vijayaravaghan S, Gyr N, Whitcomb DC, Khan AK, Hitman GA: SPINKI is a susceptibility gene for fibrocalculous pancreatic diabetes in subjects from Indian subcontinent. Am J Hum Genet 2002, 71:964-968.
7. Stroth $U$, Unger $T$ : The renin-angiotensin system and its receptors. J Cardiovasc Pharmacol 1999, 33:S21-28

8. Campbell DJ: Circulating and tissue angiotensin systems. J Clin Invest 1987, 79:1-6.

9. Leung PS, Carlsson PO: Tissue renin-angiotensin system: its expression, localization, regulation and potential role in the pancreas. J Mol Endocrinol 200I, 26: I 55-164.

10. Phillips MI, Speakman EA, Kimura B: Levels of angiotensin and molecular biology of the tissue renin angiotensin systems. Regul Pept 1993, 43:I-20.

II. Ruiz-Ortega M, Ruperez M, Esteban V, Egido J: Molecular mechanisms of angiotensin II-induced vascular injury. Curr Hypertens Rep 2003, 5:73-79.

12. Bataller R, Gines P, Nicolas JM, Gorbig MN, Garcia Ramealo E, Gasull $\mathrm{X}$, Bosch J, Arroyo V, Rodes J: Angiotensin II induces contraction and proliferation of human hepatic stellate cells. Gastroenterology 2000, I I 8: I |49- I I 56.

13. Marshall RP, McAnulty RJ, Laurent G]: Angiotensin II is mitogenic for human lung fibroblasts via activation of the type I receptor. Am J Respir Crit Care Med 2000, I 6 I: 1999-2004.

14. Erdos E, Skidgel RA: The angiotensin I-converting enzyme. Lab Invest 1987, 56:345-348.

15. Ip SP, Kwan PC, Williams CH, Pang S, Hooper NM, Leung PS: Changes of angiotensin-converting enzyme activity in the pancreas of chronic hypoxia and acute pancreatitis. Int J Biochem Cell Biol 2003, 35:944-954.

16. Leung PS, Chan HC, Nobiling R: Regulated expression of pancreatic renin angiotensin system in experimental pancreatitis. Mol Cell Endocrinol 2000, 166:121-128.

17. Friedman SL: Molecular regulation of hepatic fibrosis, an integrated response to injury. I Biol Chem 2000, 275:2247-2250.

18. Okuno M, Akita K, Moriwaki H, Kawada N, Ikeda K, Kaneda K, Suzuki Y, Kojima S: Prevention of rat hepatic fibrosis by the protease inhibitor, camostat mesilate, via reduced generation of active TGF- $\beta$. Gastroenterology 200I, 20: I784-I800.

19. Schneider E, Schmid-Kotsas A, Zhao J, Weidenbach H, Schmid RM, Menke A, Adler G, Waltenberger J, Grunert A, Bachem MG: Identification of mediators stimulating proliferation and matrix synthesis of rat pancreatic stellate cells. Am J Physiol 200I, 28I:C532-C543.

20. Apte MV, Haber PS, Darby SJ, Rodgers SC, McCaughan GW, Korsten MA, Pirola RC, Wilson JS: Pancreatic stellate cells are activated by proinflammatory cytokines: implications for pancreatic fibrogenesis. Gut 1999, 44:534-54I.

2I. Haber PS, Keogh OW, Apte MV, Moran CS, Stewart NL, Crawford DHG, Pirola RC, McCaughan GW, Ramm GA, Wilson JS: Activation of pancreatic stellate cells in human and experimental pancreatic fibrosis. Am J Pathol 1999, I 55: 1087-1095.

22. Kuno A, Yamada T, Masunda K, Ogawa K, Sogawa M, Nakamura S, Nakazawa T, Ohara H, Nomura T, Joh T, Shirai T, Itoh M: Angiotensin- Converting Enzyme attenuates pancreatic inflammation and fibrosis in male Bonn/Kabori rats. Gastroenterology 2003, I24:1010-1019.

23. Rigat B, Hubert C, Alhenc-Gelas F, Corvol P, Soubrier F: An insertion/deletion polymorphism in angiotensin converting enzyme gene accounting for half the variance of serum enzyme levels. J Clin Invest I990, 86: | 343-I346.

24. Cambien F, Poirier O, Lecerf L, Evans A, Cambou JP, Arveiler D, Luc G, Bard JM, Bara L, Richard S: Deletion polymorphism in the gene for angiotensin converting enzyme is a potent risk factor for myocardial infarction. Nature 1992, 359:64|-644.

25. Vishwanathan V, Zhu Y, Bala K, Dunn S, Snehalatha C, Ramachandran A, Jayaraman M, Sharma K: Association between ACE gene polymorphism and diabetic nephropathy in South Indian patients. JOP 200I, 2:83-87.

26. Oruc N, Lamb J, Kutlu OC, Barmada MM, Money ME, Slivka A, Whitcomb DC: The functional angiotensin converting enzyme gene I/D polymorphism does not alter susceptibility to chronic pancreatitis. JOP 2004, 5:457-463.

27. WHO study group Report on Diabetes Mellitus: WHO technical report series 727. Geneva 1985

28. Miller SA, Dykes DD, Polesky HF: Simple salting out procedure for extracting DNA from human nucleated cells. Nucleic Acids Res 1988, 16:1215.

29. Witt H, Luck W, Hennies HC, Classen M, Kage A, Lass U, Landt $O$, Becker $M$ : Mutations in the gene encoding the serine protease 
inhibitor, Kazal typel are associated with chronic pancreatitis. Nat Genet 2000, 25:213-216.

30. Lalouel JM, Rohrwasser A: Power and Replication in Case-Control Studies. Am J Hypertens 2002, I5(2 Pt I):20I-205.

31. Mohan V, Barman KK, Rajan VS, Chari ST, Deepa R: Natural history of endocrine failure in tropical chronic pancreatitis: a longitudinal follow-up study. J Gastroenterol Hepatol 2005, 20:1927-1934.

32. Pueyo ME, N'Diaye N, Michael JB: Angiotensin II elicited signal transduction via AT-I receptors in endothelial cells. Br J Pharmacol 1996, I 1 8:79-84.

33. Nagashio $Y$, Asaumi $H$, Watanabe $S$, Nomiyama $Y$, Taguchi M, Tashiro $M$, Sugaya T, Otsuki M: Angiotensin II type I receptor interaction is an important regulator for the development of pancreatic fibrosis in mice. Am J Physiol Gastrointest Liver Physiol 2004, 287:GI70-I77.

34. Chandak GR, Idris MM, Reddy DN, Mani KR, Bhaskar S, Rao GV, Singh L: Absence of PRSSI mutations and association of SPINKI trypsin inhibitor mutations in hereditary and nonhereditary chronic pancreatitis. Gut 2004, 53:723-728.

\section{Pre-publication history}

The pre-publication history for this paper can be accessed here:

http://www.biomedcentral.com/1471-230X/6/42/pre

pub

Publish with Biomed Central and every scientist can read your work free of charge

"BioMed Central will be the most significant development for disseminating the results of biomedical research in our lifetime. "

Sir Paul Nurse, Cancer Research UK

Your research papers will be:

- available free of charge to the entire biomedical community

- peer reviewed and published immediately upon acceptance

- cited in PubMed and archived on PubMed Central

- yours - you keep the copyright

Submit your manuscript here:

http://www.biomedcentral.com/info/publishing_adv.asp 